\title{
Evolution and Transformation of Real Estate Dynamics in the City of Milan
}

\author{
Liala Baiardi ${ }^{(\bowtie)}$ and Andrea Ciaramella \\ Politecnico di Milano, Milan 20133, Italy \\ liala.baiardi@polimi.it
}

\begin{abstract}
With the foundation of metropolitan cities, we have witnessed a transition that has implemented the drivers of change and innovation in large cities, towards the production of knowledge and all the resources necessary to face international competition and overcome possible structural crises on a territorial basis.

This article shows some results of a study on Italian metropolitan cities, to investigate the extent to which the values of the real estate market and land revenues are linked to the performance of the cities and the territory.

Through a series of parameters and the grouping of investments by the main real estate players, this study seeks to answer the following research question: following the development activities in the Italian metropolitan cities, did real estate properties increase their value and their revenues?

The phenomenon of urbanization of metropolitan cities is analyzed by proposing a framework for the analysis of the real estate profile on a metropolitan-tan scale, in order to understand the role of this entity in relation to aspects of social cohesion and economic-environmental sustainability.
\end{abstract}

Keywords: Real estate development $\cdot$ Investment $\cdot$ Metropolitan cities

\section{Introduction}

With the establishment of "metropolitan cities", approved by the Italian government in 2014 (L. 7 April 2014, n. 56 on "Provisions on metropolitan cities, provinces, unions and mergers of municipalities"), we have witnessed a significant transition. The establishment of metropolitan cities requires overcoming the critical issues and links that these contexts face on different scales and dimensions - mainly economic, environmental and social - including aspects relating to the variation of settlement/ functional trends and the complexities of urban transformation/regeneration processes and building restoration.

In this scenario, which reveals an increasing competitiveness between territory, cities, geographical areas and territorial systems, public institutions are involved in the relaunching and requalification activities. They are aware of the fact that in the competition between urban areas the most dynamic "systems" able to combine the protection of their territory with the development hypotheses will be awarded [1].

Metropolitan cities have been entitled to become drivers of change and innovation, privileged centers of knowledge production, powerful competitors in international 
markets, and enablers to overcome crises [2]. Metropolitan cities are expected to demonstrate "the capacity to recover quickly from difficulties" [3], hence to tow territories toward resilience, as for the Oxford dictionary's definition.

The paper analyzes the metropolitan dynamics an focus on Milanese experience as an example of urban resilience, by exploring the real estate strategies that supported the recovery from the crisis.

\section{Methodology of Investigation}

In the last ten years, extensive researches have sought to assess the dynamics involved in the metropolitan cities by comparing them with one another. Most of these studies have defined synthetic indicators to measure urban smartness [4] and also its dimensions and productivity [5].

Some observers note that although indicators are a powerful means of describing complex phenomena and supporting decision-making processes to define effective strategies and urban actions, they may sometimes be ineffective for measuring elements such as social, demographic, and cultural differences between cities [6, 7].

The Research Project of Relevant National Interest - PRIN "Metropolitan cities: territorial economic strategies, financial constraints and circular regeneration" his aimed to improve the knowledge system regarding the functions, structure and performance of Metropolitan Cities, as well as the role to be assigned to second and third order cities, "territorial order centers", in a context of reduced functionality and tendential disappearance of the Provinces.

The analysis of the real estate profile implies data processing, after gathering information from the principal official sources reporting the national real estate market behavior.

We analyzed official data provided by the main real estate operators and also focus on data from the Real Estate Market Observatory (Italian OMI - Osservatorio del Mercato Immobiliare), and large database, provided to Politecnico by "Il Quotidiano Immobiliare" - QI (https://www.ilqi.it/post/quotidiano-immobiliare), the first Italian online magazine and search engine about real estate issues.

The results of these multiple-method examination will be presented in the following sections of this paper.

\section{Metropolitan Cities and Real Estate Investments in Italy}

In Italy, the law of April 7, 2014 no. 56 the establishment, redefining the provincial system. The measure identified ten metropolitan cities. According to the geographical areas defined by the Italian National Institute of Statistics (ISTAT), the 10 cities approved by the law 2014 no. 56, were structured into three classes [8]:

- Northern metropolitan cities: Turin, Milan, Genoa and Bologna;

- Central metropolitan cities: Florence and Rome;

- Southern metropolitan cities: Bari, Naples, Reggio Calabria. 
Later, four other metropolitan cities have been identified by the special statute regions Cagliari (Sardinia); Catania (Sicily); Messina (Sicily); Palermo (Sicily).

\subsection{Metropolitan Cities}

As acquired by the main institutional sources [9-11], the Italian metropolitan cities are very heterogeneous in terms of both population size and area, as well as levels of wellbeing and socio-economic development and, more generally, the extent of urban infrastructure.

By referring just to demographic for example, ISTAT data show that in 2017 the population of the 10 capital cities was about $8,000,000$ (16\% of the Italian population), while that of the metropolitan areas was about 18,5 million (33\% of the Italian population).

Table 1. Population, area and density of the metropolitan cities (Source: Polytechnic elaboration on data from "ISTAT 2017").

\begin{tabular}{lccccccc}
\hline Capital city & $\begin{array}{c}\text { Dimension } \\
(\mathrm{kmg})\end{array}$ & $\begin{array}{c}\text { Population } \\
\text { (Istat 2017) }\end{array}$ & $\begin{array}{c}\text { Capital City } \\
\text { density } \\
\text { (inhab./kmq) }\end{array}$ & $\begin{array}{c}\text { Metropolitan } \\
\text { area } \\
\mathbf{n}^{\circ} \text { municipalities }\end{array}$ & $\begin{array}{c}\text { Dimension } \\
(\mathrm{kmg})\end{array}$ & $\begin{array}{c}\text { Population } \\
\text { (Istat 2017) }\end{array}$ & $\begin{array}{c}\text { Metropolitan } \\
\text { area density } \\
\text { (inhab, } / \mathrm{kmg})\end{array}$ \\
\hline Roma & $1.287,36$ & $2.873 .494,00$ & $2.232,08$ & 121,00 & $5.363,28$ & $4.353 .738,00$ & 811,77 \\
Milano & 181,67 & $1.351 .562,00$ & $7.439,65$ & 134,00 & $1.575,65$ & $3.218 .201,00$ & $2.042,46$ \\
Napoli & 119,02 & $970.185,00$ & $8.151,45$ & 92,00 & $1.178,93$ & $3.107 .006,00$ & $2.635,45$ \\
Torino & 130,01 & $886.837,00$ & $6.821,30$ & 316,00 & $6.817,28$ & $2.277 .857,00$ & 334,13 \\
Bari & 117,39 & $324.198,00$ & $2.761,72$ & 41,00 & $3.862,88$ & $1.260 .142,00$ & 326,22 \\
Firenze & 102,32 & $382.258,00$ & $3.735,91$ & 42,00 & $3.513,69$ & $1.014 .423,00$ & 288,71 \\
Bologna & 140,86 & $388.367,00$ & $2.757,11$ & 55,00 & $3.702,32$ & $1.009 .210,00$ & 272,59 \\
Genora & 240,29 & $583.601,00$ & $2.428,74$ & 67,00 & $1.833,79$ & $850.071,00$ & 463,56 \\
Venezia & 415,90 & $261.905,00$ & 629,73 & 44,00 & $2.472,91$ & $854.275,00$ & 345,45 \\
Reggio Calabria & 239,04 & $182.551,00$ & 763,68 & 97,00 & $3.210,37$ & $553.861,00$ & 172,52 \\
\hline & $\mathbf{2 . 9 7 3 , 8 6}$ & $\mathbf{8 . 2 0 4 . 9 5 8 , 0 0}$ & $\mathbf{2 . 7 5 9 , 0 3}$ & $\mathbf{1 . 0 0 9 , 0 0}$ & $\mathbf{3 3 . 5 3 1 , 1 0}$ & $\mathbf{1 8 . 4 9 8 . 7 8 4 , 0 0}$ & $\mathbf{5 5 1 , 6 9}$ \\
\hline
\end{tabular}

The cities vary greatly as regards population and density: Rome, for example, has over 2,800,000 inhabitants while Reggio Calabria has about 240,000. The population share of the capital city compared to the metropolitan area (see Table 1) varies between the maximum value of Genoa, where about $70 \%$ of the population is concentrated in the capital, and Bari (26\%).

The lack of homogeneity is also highlighted by a series of critical issues including:

- the lack of a true integration between the city center and the metropolitan hinterland, beyond a historical structure that sees the hinterland hosting mainly industrial activities [12]; 
- the difficulty for the metropolitan belts to find true new economic vocations capable of compensating for the tendential reduction of industrial jobs;

- the fiscal-financial crisis of the new CMs, lacking - as is the case in the French case - of their own taxation and of adequate resources for the important tasks assigned to them [13];

- the absence in our country of a tradition of strategic planning on a vast, metropolitan scale;

- the collapse, which occurred in the last decade and not only since the crisis, of public, national and local investments, as a result of the overall fiscal crisis in the country, with the major cities leading the decline [14].

\subsection{Real Estate Transaction by Building Type in Italy}

Focusing on real estate transactions (deals) recorded in Italy by QI with a minimum amount of 5 million euros, from 2012 to 2017. These account for over 500 records. From the analysis of this database, we can formulate a few considerations regarding the building types and the most active cities in the Italian real estate market, in relation with the general investments.

Real estate operations concentrate mainly in the tertiary sector (see Fig. 1).

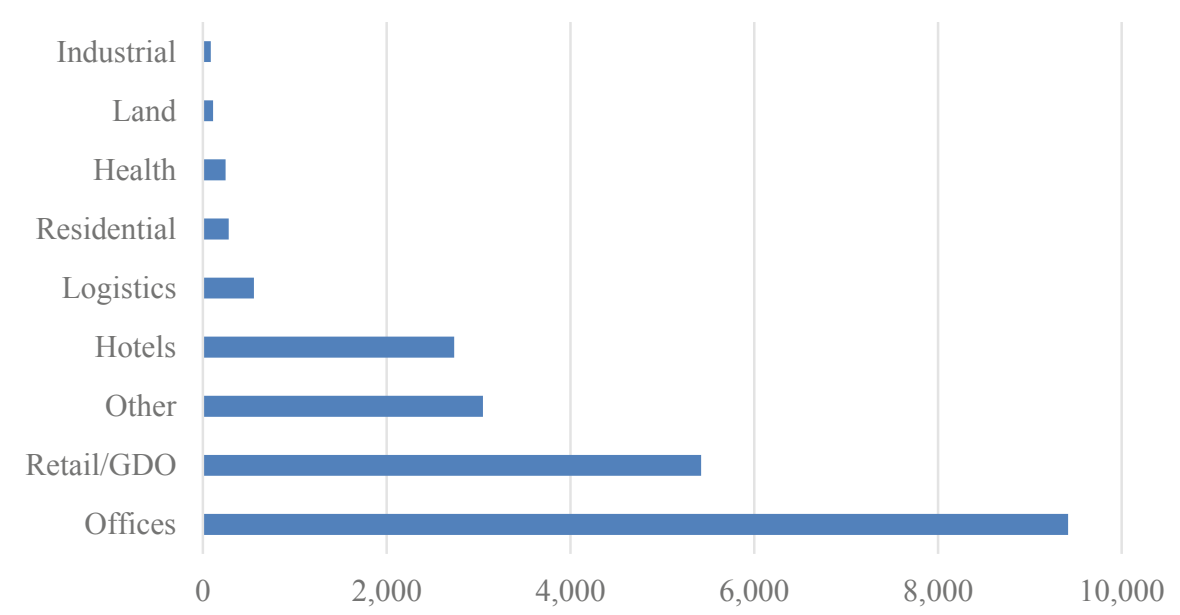

Fig. 1. Large real estate investments in Italy from 2012 to 2017 by building type (value in mln $€)$ - (Source: Polytechnic Elaboration on data from QI).

Most of the transactions in terms of value concern the purchase of buildings intended for office use, which takes up to about $43 \%$ of the total investment volume (with over 9 billion invested). The retail sector follows with 25\% (over 5 billions) and hospitality with $12 \%$ (almost 3 billions). These three types alone represent more than $80 \%$ of the total volume of real estate investments. Only marginal investments are directed to other building types. Especially surprising is the limited amount of money 
devoted to housing. The census showed that investment in the residential sector represents only $1 \%$ of the total volume of investments in the Italian real estate sector.

Recent data from the Bank of Italy confirm these already explicit trends and show that the market of non-residential real estate investments in 2018 reached a record value with about 11.1 billion Euro and a growth rate of about $25 \%$ compared to 2016 [15]. The average value of single asset transactions closed in 2017 in all sectors was 37 million Euro, in line with long-term data.

\subsection{Real Estate Transactions by City}

By analyzing the location of investments (see Fig. 2), the metropolitan city preferred by investors is Milan (with over 11 billion euros in the period 2012-2017). The metropolitan city of Rome attracts only one third of the volume produced by Milan.

Milan sees more than 150 transactions above 5 million each. Rome reaches barely one third of the Milan's number and value of transactions. All other Italian metropolitan cities run far behind these records. Other provinces with relatively high performance are: Sassari (thanks to the 600 million Euros spent by a Holding of Quatar in the hotel sector), Bologna (with around 500 million invested in the commercial/retail and logistics sectors), and Turin with almost 500 million Euros distributed mainly in the tertiary and commercial/retail sectors.

Milan is confirmed as the most active city in the Italian real estate market, based on both the number of real estate transactions and their value between 2012 and 2017.

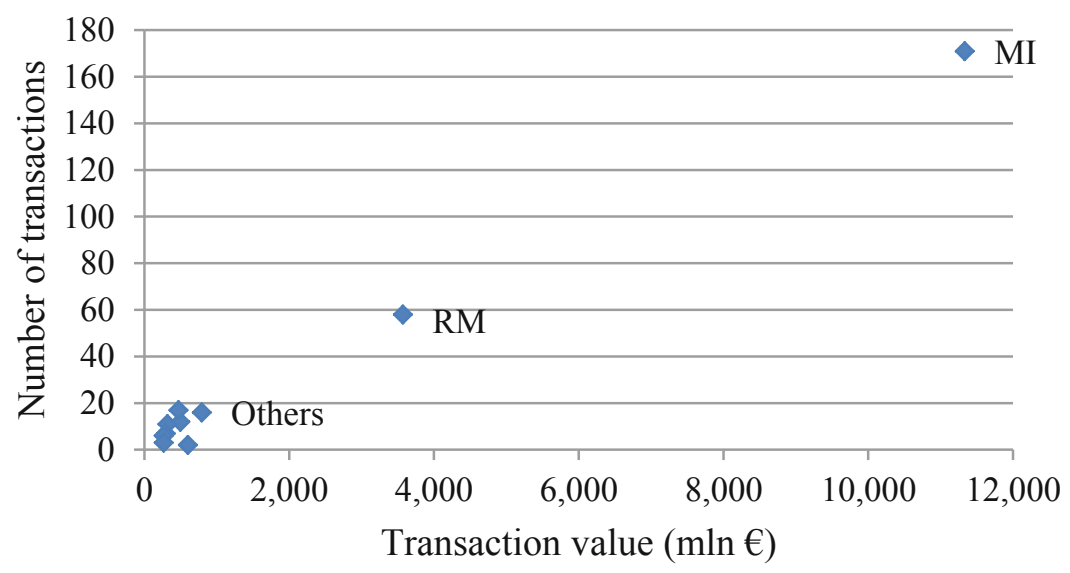

Fig. 2. Number and value of real estate deals in Italy. - Elaboration on data from QI.

\subsection{Real Estate Performance in Milan}

Taking into consideration the trends in the decade under consideration of the real estate prices (all intended uses) of the Municipality of Milan, in each OMI range (B, C, D, E zones), the trend in the individual areas seems to follow an average trend constant while the price difference between the individual zones is evident (see Fig. 3). 
Figure 3 in fact highlights a substantial difference between the average value of the prices recorded in zone $\mathrm{B}$ (central) which is approximately double compared to zone $\mathrm{C}$ (semi-central). Value that goes further towards the peripheral areas.

Between 2013 and 2014 there was a marked variation in the prices due to the previously illustrated process of ten-year revision of the territorial areas ended in 2014 .

The updating of the articulation of the municipal territory by homogeneous areas has incorporated the structural changes of the urban fabric and the local market, found through detailed territorial analyzes.

According to our elaborations on data from QI, the real estate deals in Milan distribute among the following building types: $62 \%$ offices; $9 \%$ retail; $2 \%$ hotels and $27 \%$ all the others.

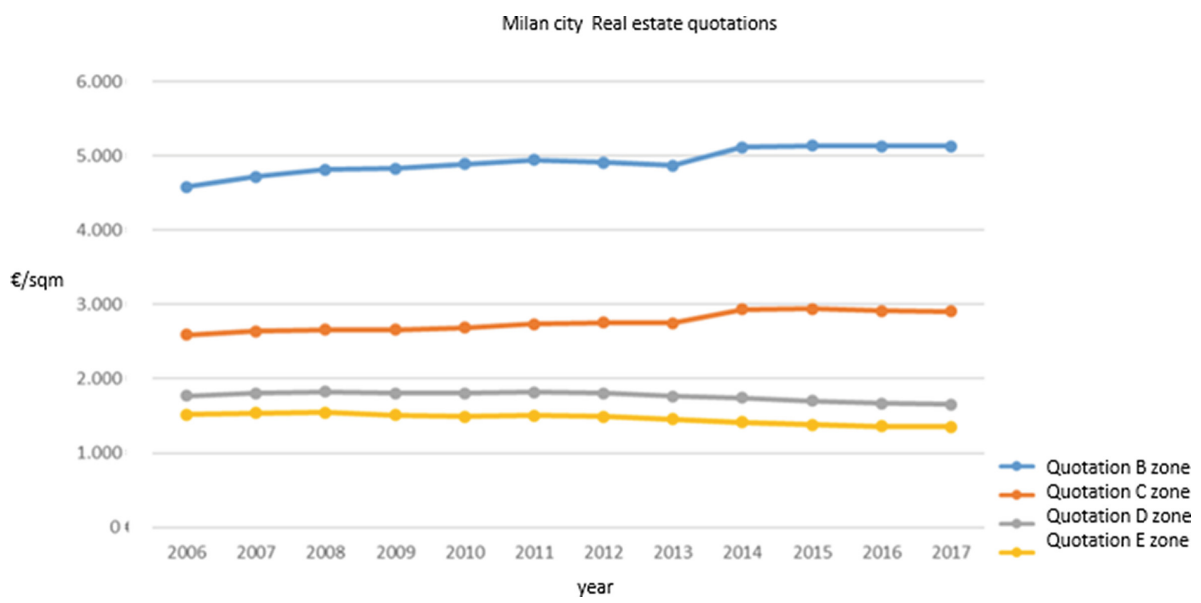

Fig. 3. Milan real estate quotations. - (Source: Polytechni Elaboration on data from OMI).

In 2016, the office building market in the metropolitan city of Milan recorded an overall growth in the volume of transactions of 67\% [16]. Surprisingly, these transactions are mainly concentrated within the Milan municipality. Deals do not concern much all the surrounding territories that compose the administrative borders of the metropolitan area. The office market of the Milan municipality registered a conspicuous increase in the area exchanged, which equals to 320,000 square meters in 2017 , compared to 280,000 in 2016 [17]. Not less important is the absorption rate, which rose from 55\% in 2016 to $64 \%$ in 2017 [17], indicating a gradual reduction in the gap between supply and demand.

\section{Conclusion}

Milan has demonstrated the ability to recover from the 2008 economic-financial crisis relatively fast and to turn the difficulties into chances for redevelopment. In the last five years, the commercial real estate market has become increasingly active. 
We found out that these operations tend to concentrate in a few poles, as they have been encouraged by public initiatives that were directed to regenerate entire areas of the city, such as the Porta Nuova District. Many companies have invested in a number of initiatives, directed both to building development and enhancement, which have concurred to reactivate the local market and economy. Our paper examined the most recent commercial real estate initiatives, in order to explain how they helped the Milan metropolitan area to develop a resilient attitude.

The investments seem mostly interested in moving to these new areas, in first-hand premises, suitable to boost the company's image by being aesthetically impactful and environmentally sustainable.

Real estate initiatives can regenerate urban areas while boosting economic, environmental and social activities. Our research endorses that urban resilience goes handin-hand with this kind of initiatives. Companies produce knowledge, compete in international markets, and contribute to overcoming the crises. Public authorities should prioritize the attraction of investors and organizations that are interested in real estate initiatives, as they can increase urban resilience.

The case of Milan confirms the attractiveness of metropolitan cities that become the privileged contexts for multiple businesses to settle.

Acknowledgments. This research has been funded by the Research Project of Relevant National Interest (PRIN) entitled "Metropolitan Cities: Economic-territorial strategies, financial constraints, and circular regeneration". This PRIN project is carried out by Politecnico di Milano in partnership with the University of Bari "Aldo Moro", Naples "Federico II", and Venice "IUAV" (are members of the research group of the Milan Polytechnic: Prof. Roberta Capello responsible for the project, L. Baiardi, S. Bellintani, R. Camagni, A. Caragliu, A. Ciaramella, G. Cia, A. Celani, M. Morena, V. Puglisi, C. Tagliaro, O. Tronconi).

"Il Quotidiano Immobiliare" - QI (https://www.ilqi.it/post/quotidiano-immobiliare), the first Italian online magazine and search engine about real estate issues,

Real Estate Market Observatory (Italian OMI - Osservatorio del Mercato Immobiliare) is the principal official sources reporting the national real estate market behaviour and, on the basis of a partnership deal between Italian IRS "Agenzia delle Entrate" and Politecnico di Milano ABC Department, collaborated to this project by providing us with a database occurring in Italy from 2012 to 2017. The analysis proposed in this paper are largely based on this information.

\section{References}

1. Baiardi, L.: La globalizzazione e i cambiamenti delle aree urbane. In: Baiardi, L., Morena, M. (eds.) Marketing Territoriale. Ed Il sole 24 Ore, Milano (2009)

2. Zilli, S.: Città metropolitane e resilienza territoriale. In: Viganoni, L. (ed.) Commercio, Consumo e Città: Quaderno di Lavoro. Pratiche, Pianificazione e Governance per l'inclusione, la Resilienza e la Sostenibilità" Urbane. Franco Angeli, Milano (2017)

3. Oxford Dictionaries. Resilience. Oxford Dictionaries (2019). https://en.oxforddictionaries. com/definition/resilience. Accessed 28 Feb 2019

4. Giffinger, R., Fertner, C., Kramar, H., Kalasek, R., Pichler-Milanovic, N., Meijers, E.: Smart Cities: Ranking of European Medium-Sized Cities. Centre of Regional Science (SRF), Vienna University of Technology, Vienna, AU (2007) 
5. Caragliu, A., Del Bo, C., Nijkamp, P.: Smart cities in Europe. J. Urban Technol. 18, 65-82 (2011). https://doi.org/10.1080/10630732.2011.601117

6. Kitchin, R., Lauriault, T.P., McArdle, G.: Knowing and governing cities through urban indicators, city benchmarking and real-time dashboards. Reg. Stud. Reg. Sci. 2(1), 6-28 (2015). https://doi.org/10.1080/21681376.2014.983149

7. Vanolo, A.: Smartmentality: the smart city as disciplinary strategy. Urban Stud. 51, 883-898 (2014). https://doi.org/10.1177/0042098013494427

8. ISTAT (Istituto Nazionale di Statistica), Rapporto annuale (2017). https://www.istat.it/it/ files//2017/05/RapportoAnnuale2017.pdf. Accessed 12 Nov 2018

9. ARUP. Smart actions in Italian metropolitan cities (2013). https://www.arup.com/ publications/research/section/smart-actions-in-italianmetropolitan-cities. Accessed 12 Nov 2018

10. DARA (Dipartimento per gli Affari Regionali e le Autonomie). I dossier delle Città Metropolitane (2017). http://www.affariregionali.it/comunicazione/dossier-e-normativa/idossier-delle-citt\%C3\%A0-metropolitane/. Accessed 04 Oct 2019

11. Censis. Rileggere i territori per dare identità e governo all'area vasta. Il governo delle aree metropolitane in Europa. Report di ricerca (2014). http://province.usb.it/documenti.html? eID=dam_frontend_push\&docID=464. Accessed 12 Nov 2018

12. Calafati, A. (a cura di): Città tra sviluppo e declino. Un'agenda urbana per l'Italia. Donzelli Editore, Roma (2015)

13. Ires-Irpet-Eupolis: La finanza territoriale - Rapporto 2014. Franco Angeli, Milano (2014)

14. Camagni, R., Capello, R., Caragliu, A.: Static vs. dynamic agglomeration economies: spatial context and structural evolution behind urban growth. Reg. Sci. 95, 133-158 (2015). https:// doi.org/10.1111/pirs. 12182

15. BNP Paribas Real Estate: At a glance-Q1 2018. Investimenti in Italia, Milano (2018)

16. Scenari Immobiliari: Milano Challenger 'sul Podio d'Europa'. Rapporto 2017 Mercato Immobiliare di Milano e Area Metropolitana (2017)

17. Pwc: Real Estate Market Overview Italy 2017 (2018)

18. Colliers International Italia: Italia INVESTIMENTI. Market report 2017 (2018)

Open Access This chapter is licensed under the terms of the Creative Commons Attribution 4.0 International License (http://creativecommons.org/licenses/by/4.0/), which permits use, sharing, adaptation, distribution and reproduction in any medium or format, as long as you give appropriate credit to the original author(s) and the source, provide a link to the Creative Commons license and indicate if changes were made.

The images or other third party material in this chapter are included in the chapter's Creative Commons license, unless indicated otherwise in a credit line to the material. If material is not included in the chapter's Creative Commons license and your intended use is not permitted by statutory regulation or exceeds the permitted use, you will need to obtain permission directly from the copyright holder.

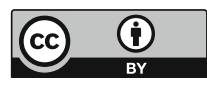

